\title{
EXPRESSION OF THE OPPRESSED: USING CRITICAL PEDAGOGY IN ARTS EDUCATION TO DISRUPT SYSTEMS OF OPPRESSION
}

\section{S. Rebeqa RIVERS *}

Independent Researcher, USA

\begin{abstract}
In 1970, Paulo Freire introduced critical pedagogy in Pedagogy of the Oppressed. Since that time, critical pedagogy has been widely applied in general education and has slowly integrated into music, theatre, dance, and visual arts education. Rooted in the critical examination of power, critical pedagogy is a way of critically examining how we conceptualize, navigate, and reimagine the relationship between teacher, student, and the established knowledge being taught in the classroom. Critical pedagogues argue that selectively teaching knowledge representing certain viewpoints while omitting other viewpoints fosters hegemony - dominance of one group over another - in the classroom. Such educational inequities and exclusion are tied to disaffection, social fragmentation and conflicts. Arts education is not exempt from curricular hegemony. The longstanding practice of grounding arts education in definitions of 'artistic value' as determined by dominant social groups makes the field resistant to critical pedagogy. By applying critical pedagogy, arts educators can break the cycle of hegemony and instead foster the principles of equity, recognition, and inclusion.
\end{abstract}

Keywords

Paulo Freire, Problem-Posing, Critical Pedagogy, Arts Education, Oppression, Hegemony, Pedagogy of the Oppressed.

\section{Introduction}

In 1970, Paulo Freire introduced critical pedagogy through Pedagogy of the oppressed. Since then, critical pedagogy has been widely evaluated and applied in general education (Giroux, 1997; McLaren, 1994; Shor, 1992; McClafferty, K., Torres \& Mitchell, 2000) and has slowly integrated into music, theater, dance, and visual arts education (Abrahams 2005; Allsup, 2003; Boal, 1985; Heiland, 2016; Lamb, 1996; Peters, 2016; Regelski, 1998, 2004). Rooted in the critical examination of power, critical pedagogy is "a way of thinking about, negotiating, and transforming the relationship among classroom teaching, production of knowledge, the institutional structures of the school, and the social and material relations of the wider community, society, and nation-state" (McLaren, 1999, p. 51).

Critical pedagogues have argued that teaching the selective viewpoints of one group while omitting other viewpoints fosters hegemony - or dominance of one group over another - in

\footnotetext{
*Corresponding author: rebeqarivers@gmail.com
} 
the classroom. Often, curricular knowledge is selected to reproduce dominant cultural and social values. Once such values are entrenched in the interpersonal and institutional settings, they permeate society, are assumed tobe 'common sense', and go unchallenged. (Krancberg, 1986; Litowitz, 2000). This becomes problematic when the values infiltrating social norms are ones that uphold oppressive, hegemonic ideologies.

The cost of hegemony in the classroom is personally and societally steep. Students who receive differential treatment in the classroom are more likely to drop out of school (Skiba et al., 2002). When such individuals lose access to education, they are less likely to secure jobs that adequately support their future families and are more likely to face jail time as adults (Noguera, 2003; Rocque \& Paternoster, 2011). Those students who manage to stay in school and resist a hegemonic environment often cope through disengagement and defiance (Miron \& Lauria, 1998). On a societal level, systemic inequities and exclusion are linked to disaffection, social fragmentation and conflicts (UNESCO, 2012).

Arts education is not exempt from curricular hegemony. The longstanding practice of grounding arts education in definitions of 'artistic value' as determined by dominant social groups makes the field resistant to critical pedagogy. In the United States, for example, there exists an historic campaign to rehabilitate the musical tastes of poor social classes from 'low' culture to 'high' culture (Seeger, 1957). This influence is still reflected by the country's strong preference to fund curricula for Western European orchestral, band, and choral traditions, despite an increasingly diversified population (Jones, 2004; US Census, 2010). By applying critical pedagogy, arts educators can break the cycle of hegemony and instead foster the principles of equity, recognition, and inclusion.

\section{SYSTEMS OF OPPRESSION}

Oppression occurs when people are repeatedly denied equitable access to freedom, opportunity, justice, or other elements of human experience based on facets of their identity. Bell identified the four "I's" of oppression - Ideological, Institutional, Interpersonal, and internalized oppression - as a systemic framework of interrelated parts that cannot exist independently (Bell, 2013). Ideological oppression forms the foundation and stems from "the idea that one groupis somehow better than another, and in some measure has the right to control the other group" (Bell, 2013, p. 1). Institutional oppression occurs when ideological oppression becomes "embedded in the institutions of society - the laws, the legal system, and police practice, the education system and schools, hiring policies, public policies, housing development, media images, political power, etc.” (Bell, 2013, p. 1). Interpersonal oppression results when ideological and institutional oppression "gives permission and reinforcement for 
individual members of the dominant group to personally disrespect or mistreat individuals in the oppressed group" (Bell, 2013, p.2). Finally, when individuals of an oppressed group internalize ideological inferiority, observe it reflected in their institutions, and endure interpersonal mistreatment, internalized oppression can result (Bell, 2013, p. 2).

\section{SYSTEMS OF OPPRESSION IN EDUCATION}

The knowledge selected for curricula sets the front line example of what, and who, matter most in classrooms. Biased knowledge selection often privileges the values and practices of the dominant culture. Because hegemonic values are often ensconced into societal norms (e.g. 'this is what we have always taught'), they can become insulated from critique and evolution. Basing an education system on knowledge that is shielded from interrogation puts our curricula at risk of social and cultural obsolescence.

Holding the position to select curricular content imbues the institutional power to oppress through omission and misrepresentation. Curricular representation can impact the lives of learners and communities by endorsing cultural biases and transmitting patterns of prejudice. Koza suggested that the authority of textbooks makes them especially influential over the development of ideas and behavior (Koza, 1994, p. 29).

Since teachers operate as agents of the education system, failing to address inequities in curricular knowledge and pedagogies can constitute institutionaloppression by omission. In such cases, the intention and/or awareness of the teacher does not matter. The power imbued to them by the institution makes their actions and omissions complicit to those of the institution. Such correlations imply an ethical imperative for educators to create an inclusive learning experience for all learners. Teachers must ask the questions, 'who selects knowledge?' and 'whose voices are represented?' of all curricula.

\section{SYSTEMS OF OPPRESSION IN ARTS EDUCATION}

Similar to general education, arts curricula are often built around hegemony. Such bias does not just harm individuals against whom a curriculum shows prejudice; it communicates ideologies of inequity to their classmates. For example, when females are neglected or stereotyped in music curricula, it not only creates an inequitable experience for female students who do not see themselves accurately represented, it also damages male learners who absorb systems of gender inequity (O'Toole, 2005, p. 297).

Arts education traditions demonstrate a history of avoiding the type of critical examination that challenges social systems of oppression. Regarding music education, Horsley pointed to the "historical avoidance of issues related to politics, citizenship, and social justice" (Horsley, 2015, p. 63). Regarding visual arts education, Peters highlighted the lack of critical study 
"particularly as it relates to politics, agency, and social justice" (Peters, 2016, p. 1).

The subjective nature of 'artistic value' compounds the challenge of incorporating critical pedagogy into arts education. When an art form originated by a dominant group is classified as 'better' (ideological oppression) and receives media exposure, state funding, and community support while artists from marginalized groups are denied access to opportunities (institutional oppression) the trajectory from subjective artistic value to oppression is clear. In the United States, for example, the ideology of white supremacy fuels the institutionalized prioritization of state funding for the performance of European Opera over Rap and Hip Hop, two musical traditions of the marginalized Black community. Amazingly, this institutionalized hierarchy persists despite the gradual decline of Opera attendance and Rap and Hip Hop emerging as the dominant genre for U.S. listening consumption (NEA Report, 2017; Nielsen Report, 2017).

\section{CHALLENGING SYSTEMS OF OPPRESSION IN ARTS EDUCATION}

In Pedagogy of the oppressed, Freire proposed a metaphor to illustrate the traditional education model: Banking Education, where teachers 'deposit' knowledge into students' minds. In Banking Education, learning is a one-way transaction where students passively accept knowledge. Counter to Banking Education, Freire developed problem-posing Education, a critical pedagogy where the teacher poses problems about the knowledge and prompts students to scrutinize it in relationship to their own world experience. Learning becomes a critical investigation and students actively participate in the education process. (Freire, 1970).

Arts educators can challenge systems of oppression and take steps to disrupt hegemony by using problem-posing to critique power structures. Since this is a pedagogical approach rather than a curricular revision, educators can begin applying to any existing curriculum. For example, if studying Romantic, European composers

- say, Beethoven, Brahms, and Liszt - a problem-posing teacher might prompt, 'Why are all of these composers male?' 'Who decided that we should study these composers and not others?' 'What might have led to this group of composers gaining reverence while others are lost to history?' 'How well do you think this group of composers reflects the society of that time?' or 'How does it impact our current society when schools prioritize the work of European, male composers?'

One of the benefits of problem-posing is that by exposing curriculum tohealthy critique, curricular knowledge can expand and evolve. For example, after asking the questions listed above, teacher and students might decide to research female and non-white Romantic composers to include alongside Beethoven, Brahms, and Liszt. This ensures future students benefit from a curriculum that dignifies the artistic works of diverse individuals. 
Abrahams summarized five descriptive principles of problem-posing pedagogy: 1) it is a conversation between learner and teacher involving problem- posing and solving; 2) it expands the learner's understanding of reality; 3) it produces conscientization, or mature understanding beyond basic knowledge retention; 4) it reshapes the viewpoints of both teacher and learner; and 5) it is political and demands critical examination of power structures in all levels of local and global society (Abrahams, 2005, pp. 3-4). Abrahams posited that successful problemposing will reflect each of these five principles. For example, each of these principles is demonstrated in our hypothetical Romantic composer class interaction, and so we might deem it a success.

As Bell noted, the four "I's" of oppression are interrelated - impacting one disrupts them all. Consequently, by using problem-posing, arts educators can disrupt oppression in a combination of ways. For example, critiquing exclusionary curricular knowledge undermines ideological oppression by making dominant social and cultural assumptions visible. Using questions to evolve a more diverse curriculum disrupts Institutionalized Oppression by creating inclusive representation. When Ideological and institutional oppression are disrupted, students from the dominant culture are less likely to absorb hegemonic ideologies and initiate interpersonal oppression. Meanwhile, students from marginalized groups see their identities institutionally reinforced, making them less susceptible to internalizing oppressive ideologies about themselves.

\section{CONCLUSION}

Critical pedagogy has a strong legacy in general education; however, there isstill opportunity to expand its use in arts education. The institutionalized power nimbued to arts educators carries with it the responsibility to address hegemonic inequities. Failure to do so can result in: disengagement and defiance in the classroom; student attrition that reduces earning potential and increases risk of incarceration; as well as social disaffection, fragmentation, and conflicts. By applying critical education, arts educators create the opportunity to affect the interrelated systems of ideological, institutional, interpersonal, and internalized oppression.

The literature would benefit from intentional examination of how ideological, institutional, interpersonal, and internalized oppression specifically impact arts education. Additionally, the field of arts education needs to continue critically examining its traditions and assumptions for hegemonic ideologies. Such knowledge would equip arts educators with a better understanding of how to pose meaningful questions that disrupt the foundation of oppressive systems, enable knowledge to expand and evolve, and ensure future students benefit from a curriculum that dignifies the artistic works of diverse individuals. 


\section{References}

- Abrahams, F. (2005). The application of critical pedagogy to music teaching and learning. Visions of Research in Music Education, 6. Retrieved from http://wwwusr.rider.edu/ vrme/v6n1/visions/Abrahams\%20The\%20Application\%20of\%2 0Critical\%20Pedagogy.pdf

- Allsup, R. E. (2003). Transformational education and critical pedagogy: Examiningthe link between culture and learning. Music Education Research, 5(1), 5-12.

- Bell, J. (2013). The four "I's" of oppression. Somerville: YouthBuild USA.

- Boal, A. (1985). Theatre of the oppressed. New York: Theatre CommunicationsGroup.

- Freire, P. (1970). Pedagogy of the oppressed. New York: Seabury Press. Giroux, H. (1997). Pedagogy and the politics of hope. Boulder: Westview Press.

- Habermas, J. (1982).

- Horsley, Stephanie. (2015). Facing the music: Pursuing social justice through music education in a neoliberal world. In C. Benedict, P. Schmidt \& G. Spruce (Eds.), Oxford Handbook of Social Justice in Music Education, 62-77. New York: Oxford University Press.

- Jones, P. (2004). Returning music education to the mainstream: Reconnecting with the community. Paper presented at International Society for Music Education (p. 38). Madrid: Enclave Creativa Ediciones.

- Koza, J. E. (1994). Aesthetic music education revisited: Discourses of exclusion and oppression. Philosophy of Music Education Review, 2(2), 75-91.

- Krancberg, S. (1986). Common sense and philosophy in Gramsci's "prisonnotebooks". Studies in Soviet Thought, 32(2), 163-181.

- Lamb, R. (1996). Feminist pedagogy in music education. Theory into Practice, 35(2) 124-31.

- Litowitz, D. (2000). Gramsci, hegemony, and the law. Brigham Young University Law Review, 2000(2), 515-551.

- McClafferty, K., Torres, C. A., \& Mitchell, T. (2000). Challenges of urban education: sociological perspectives for the next century. Albany: State University of New York Press.

- McLaren, P. (1994). Life in schools: An introduction to critical pedagogy in the foundations of education. New York: Longman.

- McLaren, P. (1999). A pedagogy of possibility: Reflecting upon Paulo Freire's politics

- of education. Educational Researcher, 28(2), 49-54, 56. 
- Miron, L. F., \& Lauria, M. (1998). Student voice as agency: Resistance and accomodation in inner-city schools. Anthropology and Education Quarterly,29(2), 189213.

- National Endowment for the Arts. (2016). NEA 2016 annual report. Retrieved from https://www.arts.gov/sites/default/files/2016\%20Annual\%20Report\%20FINAL. pdf

- Nielsen Music. (2017). 2017 year-end music report: U.S. Retrieved from https://www.nielsen.com/content/dam/corporate/us/en/reports- downloads/2018reports/2017-year-end-music-report-us.pdf

- Noguera, P. A. (2003). Schools, prisons, and social implications of punishment: Rethinking disciplinary practices. Theory Into Practice, 42(4), 341-350.

- O’Toole, P. (2005). Praxial music education: Reflections and dialogues. Elliott, D. J. (Ed.). New York, NY: Oxford University Press.

- Peters, C. (2016). Critical pedagogy and art. In Peters, M.A. (Ed.), Encyclopedia of educational philosophy and theory (pp. 1-6). Springer: Singapore.

- Regelski, T. (1998). Critical theory as a foundation for critical thinking in music education. Studies in Music from the University of Western Ontario, 17(4), 1-21.

- Regelski, T. (2004). Teaching general music in grades 4-8: A musicianshipapproach. New York: Oxford University Press.

- Rocque, M., \& Paternoster, R. (2011). Understanding the antecedents of the"school-tojail" link: the relationship between race and school discipline.Journal of Criminal Law and Criminology, 101(2), 633-665.

- Seeger, C. (1957). "Music and Class Structure in the United States," AmericanQuarterly, 9(3), 281-94.

- Shor, I. (1992). Empowering education. Chicago: University of Chicago Press.

- Swanwick, K. (1999). Teaching music musically. London: Routledge.

- Skiba, R. J., Michael, R. S., Nardo, A. C., \& Petrson, R. L. (2002). The color ofdiscipline: Sources of racial and gender disproportionality in school punishment. Urban Review, 34(4), 317-342.

- U.S. Census Bureau. (2011, March 24). 2010 census shows America's diversity [Press release]. Retrieved from https://www.census.gov/newsroom/releases/archives/2010_census/cb11-cn125.html

- UNESCO. (2012). Addressing exclusion in education. Retrieved from https://unesdoc.unesco.org/ark:/48223/pf0000217

- $\quad$ Rosemary MARTIN, CRITICAL REFLECTIONS ON DANCE EDUCATION IN THE 
SOUTHERN MEDITERRANEAN FROM 2010 TO 2020, International Journal of Creativity and Innovation in Humanities and Education, Vol. 3 No. 1, 2020, pp. 1-16.

- Yaroslav SENYSHYN, CREATIVITY IN ARTS EDUCATION, PHENOMENOLOGY OF MUSIC AND EINSTEIN'S SCIENTIFIC INSIGHT INTO THE RELATIVITY OF TIME, International Journal of Creativity and Innovation in Humanities and Education, Vol. 3 No. 1, 2020, pp. 31-41.

Received: September 8, 2020

Accepted: November 23, 2020 